\title{
RAINFALL EROSIVITY IN NORTH-CENTRAL ANATOLIA IN TURKEY
}

\author{
OĞUZ, I. \\ Department of Soil Science and Plant Nutrition, Gaziosmanpaşa University, Tokat, Turkey \\ (e-mail: irfan.oguz@gop.edu.tr) \\ (Received $25^{\text {th }}$ Jul 2018; accepted $4^{\text {th }}$ Feb 2019)
}

\begin{abstract}
This study was performed by the reevaluation of historical Universal Soil Loss Equation using field experiment data that was obtained between 1978 and 1995 in Tokat, Turkey. In the study area, the annual average rainfall was $452 \mathrm{~mm}$ and about $50 \%$ of erosive rainfall events were less than $10 \mathrm{~mm}$. The duration of average erosive rainfall event was $6 \mathrm{~h}$ and the average event intensity was $3.83 \mathrm{~mm} \mathrm{~h}^{-1}$. The average erosive rainfall time in daylight (06:00-18:00), night (18:00-06:00) and mix rainfall conditions were 223.1 and 191.6, 450.2 min, respectively. The maximum rainfall amount, event intensity, storm erosivity, the maximum intensity of $10 \mathrm{~min}$ (IM10), the maximum intensity of $15 \mathrm{~min}$ (IM15), the maximum intensity of $30 \mathrm{~min}$ (IM30) were mostly occurred in daylight erosive rainfalls. But the maximum soil loss and runoff produced by night erosive rainfall. This situation was attributed to the short-term effect on soil erodibility of day and night temperature differences in spring which is rainfall erosivity is high for the region. Higher correlation is observed between soil loss and IM10 compared to IM30. USLE R-factor showed a good correlation with Modified Fournier Index (MFI) for the region. The Mann-Kendal and Theil-Sen Slope estimator statistics to detect the direction and magnitude of an available monotonic trend in some erosivity parameters as well as soil loss and runoff. Trend analysis showed monotonic decreasing of all rainfall physical properties, soil loss and runoff.
\end{abstract}

Keywords: rainfall erosivity, modified Fournier index, erosion index, trend analysis, soil loss, runoff, Turkey

\section{Introduction}

Erosion is the most severe and widespread environmental problem in Turkey, as well as in worldwide. In the water erosion, the rainfall erosivity is the major factor for soil loses. The universal soil loss equation (USLE) was the most common prediction model and conservation planning tool in the United States and worldwide (Wischmeier and Smith, 1978; Beasley et al., 1986; Young et al., 1989; Sharpley and Williams, 1990). The rainfall erosivity factor (R) is the one of USLE factors and represents the multiplication of rainfall energy and maximum 30 min intensity (EI30) by erosive rainfall events in a year. This rainfall erosivity index is widely used for empirical soil loss prediction. Its calculation, however, requires high temporal resolution rainfall data that are not readily available in many parts of the world (Xie et al., 2014).

Rainfall erosivity is influenced by the rainfall type, amount, occurred time and intensity of storm. In many parts of world, pluviograph records are not sufficiently available in rural areas to calculate erosivity (Renard and Freimund, 1994; Yu and Rosewell, 1996a). This limitation has, however, been met by the estimation of $\mathrm{R}$ values from rainfall amount (Ferro et al., 1991; Salako et al., 1995). Several empirical equations such as the $\mathrm{KE}>25$ (Hudson, 1971), the $\mathrm{AI}_{\mathrm{m}}$ (Lal, 1976), the Fournier index (Fournier, 1960), the Modified Fournier Index (Arnoldus, 1977) and the physicallybased A index (Sukhanovski et al., 2002) have been setting to handle R factor values from rainfall amount (Richardson et al., 1983; Renard and Freimund, 1994; Yu and Rosewell, 1996b; Salako, 2008). 
In a study conducted in Santa Catarina, Brazil, daily precipitation graphs between 1989 and 2012 were used to calculate the various indices of precipitation erosion. The indices were correlated with the respective soil losses from the standard plot of USLE and the 30 min erosivity index (EI30) of rainfall recommended for the region (Jefferson et al., 2014).

Renard and Freimund (1994) suggest the use of the MFI for areas where long term data is not available. The Fournier index has been used to describe erosivity, in several countries, e.g. Germany (Sauerborn et al., 1999), Argentina (Busnelli et al., 2006), Spain (Angulo-Martínez and Beguería, 2009), Jordan (Eltaif et al., 2010), Cape Verde (Sanchez-Moreno et al., 2014), Greece (Efthimiou, 2018).

Despite the importance of the effect of rainfall characteristics (duration, occurrence time, etc.) on erosion occurrence and sediment delivery process, studies conducted on this subject have been limited in the past decades. In a study, the role of rainfall variability and extreme events were studied in long-term landscape development. The result showed that low-intensity rainfall events with long durations, large magnitudes and less return periods, contribute significantly to total soil erosion (Baartman et al., 2013). Rainfall duration is among the most effective characteristics of erosivity factor on runoff, splash and soil loss (Katebikord et al., 2017). In Masse (Central Italy) rainfall data were used to determine of erosive characteristics of the region between 2008-2012 years. Within the data period, the rainfall total durations varied from 0.3 to $97.3 \mathrm{~h}$. A total of 228 single rainfall events was identified $\mathrm{p} \geq 1 \mathrm{~mm} 60$ of them were named erosive events and the other 168 have not produced runoff and soil loss and were named non-erosive events. In the study, rainfall depth $\mathrm{P}$, and duration $\mathrm{D}$ were determined in detail. In the 58 erosive storms have a range of $\mathrm{P}$, and $\mathrm{D}$, respectively of $7.6 \leq \mathrm{P} \leq 148.6 \mathrm{~mm}$, and $0.4 \leq \mathrm{D} \leq 97.3 \mathrm{~h}$, and the 51 non-erosive storms have a range of $1 \leq \mathrm{P} \leq 19 \mathrm{~mm}$, and $0.3 \leq \mathrm{D} \leq 19.01 \mathrm{~h}$. The rainfall of the region were defined certainly erosive if $\mathrm{D}>24 \mathrm{~h}$ and $\mathrm{P}>20 \mathrm{~mm}$ (Todisco, 2014).

The 30 min maximum intensity (IM30) value of individual rainfall event is widely used in various calculations. However, the effects of different rainfall intensity values on runoff and soil losses are investigated. In a study in Iran, the 18 erosion plots were placed on rangeland hill slopes and measured of runoff and soil loss from 2010 to 2011. Thirteen maximum rainfall intensities were calculated and some of them are presented as maximum intensity in 10, 20, 30, 40, 50, 60 and $90 \mathrm{~min}$. The kinetic energy of storms was computed by USLE R factor computation procedure (Wischmeier and Smith, 1978). The relationship between rainfall intensity and soil loss were varied across intensities. In low rainfall intensities a linear function is fitted to soil loss-rainfall intensity, and in high rainfall intensities nonlinear functions are fitted to soil lossrainfall intensity (Mohamadi and Kavian, 2015).

Runoff plot observations under natural rainfall conditions represent the primary method for conducting water and soil conservation studies (Araya et al., 2011; Phan et al., 2012). However, performing plot observations experiments is a time-consuming and resource-intensive process (Cerdan et al., 2010). In Turkey, a project was carried out to determine some factor values of USLE in 15 locations has different soil and climatic conditions. The research results of all study locations were reported in a guide (Oğuz et al., 2006). Since erosivity varies significantly from year to year, at least 15 years of data are required to obtain representative estimates of annual erosivity (Foster et al., 2003). In the project, the study duration were chosen about 20 years to better represent the climate and soil conditions of study locations. Therefore, the effect of humid, dry and 
normal climatic conditions on soil and water losses is considered to be sufficiently represented. Tokat region was one of the study locations of this national project. Soil losses and runoff records by erosive rainfall of the natural erosion plots were kept regularly between 1978-1995 years. The purpose of that study was only determine some USLE factor values of study locations so only a limited part of the data were presented. It was thought that the reevaluation of this long period natural erosion plot data could contribute to the solution of the current erosion problems of Tokat region. For this purpose this article is structured in three sections. The first part of this research we present rainfall characteristics of the study area such as several times maximum intensities, erosive rainfall duration and amounts, occurrence times of soil and runoff loss, and the correlation between soil loss, runoff and some several time maximum intensities.

Secondly, comparison of the Modified Fournier Index (MFI) and USLE R factor values for individual rainfall events.

Finally, we analyzed the trend of some rainfall characteristics, soil loss and runoff amounts and estimated the steepness of the slope used the Mann-Kendall for testing trend and Sen's slope estimator to determine trends of variables in Tokat region for the study period.

\section{Materials and methods}

The study was based on reevaluated historical natural Universal Soil Loss Equation plot data between in 1978 and 1995 in Tokat, Turkey $\left(40^{\circ} 18^{\prime} \mathrm{N}, 36^{\circ} 34^{\prime} \mathrm{E}\right)$. Tokat is located in North Central Anatolia and lies at an average altitude of $600 \mathrm{~m}$. It is situated in the area of transition from Central Anatolia to the Middle Black Sea region. The study area contains plain to moderately steep area with high vegetation entities and/or under cultivation. The major vegetation types in plain area are vegetable, sugarbeat, potato and wheat. Where, orchard and wheat are common in mild steep areas, and grassland with Graminea and Fabaceae as dominant species in the moderate steep areas, other types being shrub and meadow. The mean annual temperature is $12.6{ }^{\circ} \mathrm{C}$ and the annual precipitation is $452 \mathrm{~mm}$.

Study is conducted in Akis Soil Series, Typic Ustorthent which are moderate to well drained soils, and with standard USLE conditions at a site with the standard slope steepness of $9 \%$ and slope length of $22.13 \mathrm{~m}$. Runoff plot was framed with a $20 \mathrm{~cm}$ high border, to keep precipitation and runoff within the plot area. The plot had a collecting tank and a container tank $(0.56 \mathrm{~m}$ diameter and $1.00 \mathrm{~m}$ deep $)$ at the lower end of the slope to catch runoff and sediment.

Hourly rainfall data were collected using a tipping bucket rain gauge with totals recorded every $24 \mathrm{~h}$ from 1978 to 1995 . The rainfall charts from 1978 to 1995 were used to handle a data set of some rainfall characteristics such as amount (mm), duration (min) and time of occurrence (the $24 \mathrm{~h}$ day was separated as 06:00-18:00 h (daylight), 18:00-06:00 $\mathrm{h}$ (night) and if the rains occurred during both period we called mix). The maximum intensities of 10 (IM10), 15 (IM15) and 30 (IM30) min for each erosive rainfall were calculated from rain charts. Rainfall erosivity is computed using USLE-R Factor calculation procedure (Wischmeier and Smith, 1978) with the help of erosion index values of 30 min only (EI30). About 373 rainfall charts were analyzed for this purpose. 
Rainfall erosivity was evaluated with USLE-R factor and Modified Fournier Indices. The $\mathrm{R}$ factor is calculated with the help of Equations 1-4.

$$
E_{\text {u }}=0,119+0.0873 \log \log I
$$

where I: Intensity, $\mathrm{mm} \mathrm{h}^{-1}$; $\mathrm{E}_{\mathrm{u}}$ : Rainfall energy per unit of rainfall, $\mathrm{MJ} \mathrm{ha}^{-1} \mathrm{~mm}^{-1}$.

$$
E_{g}=E_{u} * h
$$

where $E_{g}$ : Storm energy, $\mathrm{MJ} \mathrm{ha}^{-1}$, h: Rainfall amount, mm.

$$
E I=E_{g} * I M 30
$$

where EI: Single storm erosivity, MJ mm ha ${ }^{-1} \mathrm{~h}^{-1}$; IM30: the maximum $30 \mathrm{~min}$ intensity, $\mathrm{mm} \mathrm{h}^{-1}$.

$$
R=\sum\left(E_{g} * I M 30\right)
$$

where R: Annual erosivity which occurred within in a year ( $R$ factor), MJ mm ha $\mathrm{m}^{-1} \mathrm{~h}^{-1} \mathrm{y}^{-1}$.

Fournier is developed an erosivity index (Fournier, 1960) and this index was modified by FAO (FAO, 1977) as follows (Eq. 5):

$$
M F I=\sum_{i=1}^{12} \frac{p i^{2}}{p}
$$

where pi is the rainfall in a month, $\mathrm{mm}$ and $\mathrm{P}$ is the annual rainfall, $\mathrm{mm}$.

In the meteorological variables, parametric and non-parametric approaches have been used over years. The most frequently used tests for identifying the variations in meteorological variables have been nonparametric. The most popularized approach among them is Mann-Kendal test (Kendall, 1975; Mann, 1945). The Mann-Kendall nonparametric test was used to test for trend. This test is calculated as Equation 6 (Mohtar et al., 2015; Yurekli, 2015):

$$
\mathrm{S}=\sum_{\mathrm{i}=1}^{\mathrm{n}-1} \sum_{\mathrm{j}=\mathrm{i}+1}^{\mathrm{n}} \operatorname{sgn}\left(\mathrm{x}_{\mathrm{j}}-\mathrm{x}_{\mathrm{i}}\right)
$$

where $\mathrm{n}$ is the number of event, $\mathrm{x}_{\mathrm{j}}$ and $\mathrm{x}_{\mathrm{i}}$ are the observed events, and $\mathrm{sgn}$ is the sign function.

The variance is given by Equation 7:

$$
\sigma_{\mathrm{S}}^{2}=18^{-1}\left[\mathrm{n}(\mathrm{n}-1)(2 \mathrm{n}+5)-\sum_{\mathrm{i}=1}^{\mathrm{m}} \mathrm{t}_{\mathrm{i}}\left(\mathrm{t}_{\mathrm{i}}-1\right)\left(2 \mathrm{t}_{\mathrm{i}}+5\right)\right]
$$

where $\mathrm{n}$ is number of events, $\mathrm{m}$ is the number of tied events, ti is the number of events that are tied. For sample size greater than 10 the test can be given in Equation 8: 


$$
Z_{M K}= \begin{cases}\frac{S-1}{\sqrt{\sigma_{S}^{2}}} & \text { if } \quad S>0 \\ 0 & \text { if } S=0 \\ \frac{S+1}{\sqrt{\sigma_{S}^{2}}} & \text { if } \quad S<0\end{cases}
$$

For increasing rainfall trends, the values of $Z_{M K}$ is positive and for decreasing trend the value of $\mathrm{Z}_{\mathrm{MK}}$ is negative.

Sen's estimator for slope is a nonparametric test for the steepness of the trend. For N pairs of data (Eq. 9):

$$
Q_{k}=\frac{x_{j}-x_{i}}{j-i} \text { for } k=1, \ldots, N
$$

where $X j$ and $X k$ are the values at times $j$ and $k(j>k)$, respectively. The $N$ values of Qk are ranked from smallest to largest. According to condition that $\mathrm{N}$ is odd or even, the median concerning with total $\mathrm{N}$ values of is calculated by Equation 10:

$$
\mathrm{Q}_{\text {med }}= \begin{cases}\mathrm{Q}_{[(\mathrm{N}+1) / 2]} & \text { if } \mathrm{N} \text { is odd } \\ 2^{-1}\left\{\mathrm{Q}_{[(\mathrm{N}) / 2]}+\mathrm{Q}_{[(\mathrm{N}+2) / 2]}\right\} & \text { if } \mathrm{N} \text { is even }\end{cases}
$$

The confidence interval for $\mathrm{Q}_{\mathrm{med}}$ was obtained to determine the significance of the slope.

\section{Results and discussion}

Rainfall distribution: The mean monthly rainfall and the coefficient of variation of the rainfall were recorded from 1978 to 1995 (Table 1). The annual average rainfall was $452 \mathrm{~mm}$, the minimum rainfall occurred in August and the maximum in May. The maximum and minimum annual average rainfall occurred in 1993, with $604.5 \mathrm{~mm}$ and in 1994 with $311.7 \mathrm{~mm}$, respectively.

The monthly rainfall was divided into 13 groups considering the frequencies. Monthly storm amount distribution between 1978 and 1995 in Tokat is given in Figure 1, which shows that about $78 \%$ of monthly rainfall amounts were less than $60 \mathrm{~mm}$ and only about $22 \%$ of monthly rainfall exceeded $60 \mathrm{~mm}$. In the region, the monthly rainfall exceeding $70 \mathrm{~mm}$ was relatively low. $90-100 \mathrm{~mm}$ and 120-130 $\mathrm{mm}$ monthly rainfall amount group was observed quite low frequency. No frequency was observed in the 110-120 mm monthly storm amount group.

In the study period, totally 373 erosive single storm were occurred. Erosive single rainfall events distribution between 1978 and 1995 in Tokat is given in Figure 2. As shown in Figure 2, about 50\% of erosive rainfall event were less than $10 \mathrm{~mm}$ and about $30 \%$ of erosive rainfall events were $20 \mathrm{~mm}$. Only about $20 \%$ of erosive rainfall events 
were between $30 \mathrm{~mm}$ to $130 \mathrm{~mm}$. There is a negative correlation between erosive rainfall amount and frequency. This result showed that the erosive rainfall events of Tokat region is generally occurs in low amounts.

Table 1. Monthly and annual averages of rainfall between 1978 and 1995 at Tokat city

\begin{tabular}{c|c|c}
\hline Month & Rainfall amount, mm & Coefficient of variation, \% \\
\hline Jan & 44 & 54 \\
Feb & 35 & 36 \\
Mar & 35 & 66 \\
Apr & 59 & 50 \\
May & 66 & 52 \\
Jun & 37 & 68 \\
Jul & 13 & 125 \\
Aug & 6 & 114 \\
Sep & 17 & 87 \\
Oct & 42 & 79 \\
Nov & 54 & 63 \\
Dec & 42 & 43 \\
\hline Annual average & 452 & \\
\hline
\end{tabular}

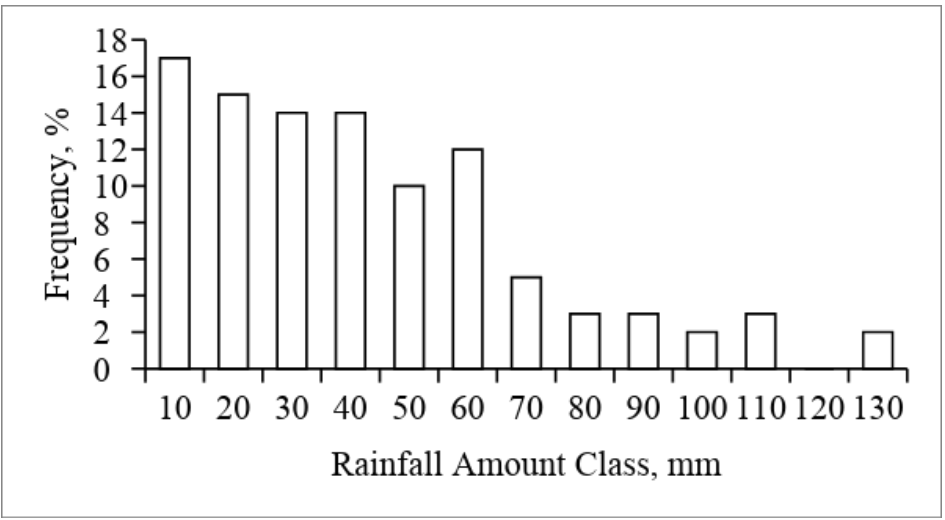

Figure 1. Monthly storm amount distribution between 1978 and 1995 at Tokat city

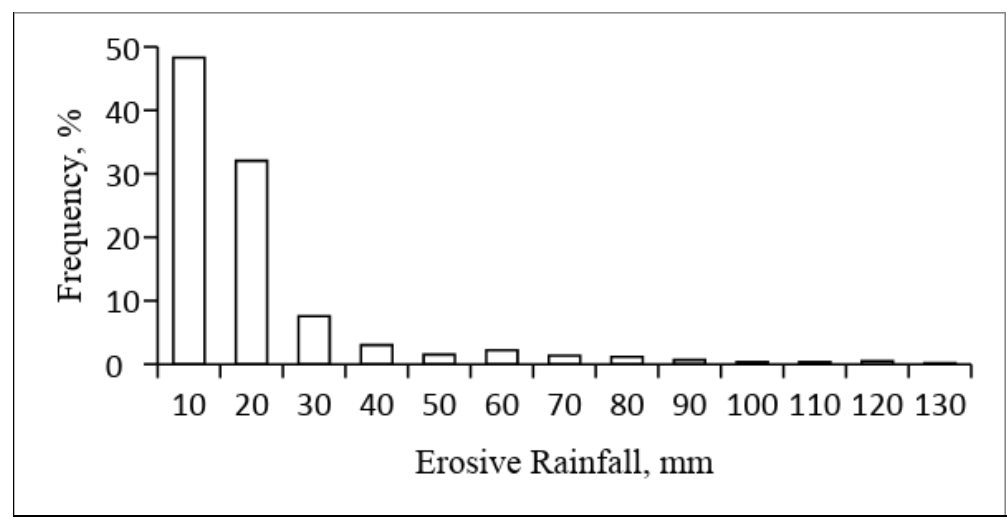

Figure 2. Erosive rainfall amount distribution between 1978 and 1995 in Tokat 
Rainfall duration, event intensity and time of occurrence: The average erosive rainfall event duration was $6 \mathrm{~h}$ and the average erosive event intensity (amount for an event/total duration) was $3.83 \mathrm{~mm} \mathrm{~h}^{-1}$. Erosive rainfall was separated according to daylight, night and mix as presented in Table 2, where differences between rainfall characteristics and soil loss and runoff in different erosive rainfall time of occurrence, are shown. In the study period, the number of the erosive rainfall occurred in daylight, night and mix conditions were 74, 73 and 226, respectively.

Average erosive rainfall duration in daylight, night and mix rainfall conditions were 223.11, 191.58, and $450.18 \mathrm{~min}$, respectively (Table 2). The average night erosive rainfall duration was observed shorter than the other types. Mix rainfall has been found having the longest rainfall duration. Jingi et al. (2011) studied the effect of rainfall duration $(5,10,15,20,25$, and $30 \mathrm{~min})$ on separation of soil grains and splash erosion using splash collecting container, and their results indicated significant positive effect of rainfall duration on soil splash. But under natural rainfall conditions, an erosive rainfall has usually variable intensities. When a rain takes place in a prolonged period of time, it generally causes the variables intensities of this rain to achieve lower energy levels. Therefore, the long erosive rainfall duration mostly causes less soil loss and runoff than shorter erosive rainfall duration. The erosive rainfall duration of daylight took place between erosive rainfall duration of mix and night conditions. The average night erosive rainfall amount was also at the lowest levels. The daylight was moderate, and the mix had maximum rainfall amount.

Average erosive event intensity in daylight, night and mix rainfall conditions were $6.92,4.51,2.60 \mathrm{~mm} \mathrm{~h}^{-1}$ respectively. Maximum event intensity took place in daylight erosive rainfall and minimum was in mix rainfall. Likewise storm erosivity (EI) was 35.72, 23.80 and 18.65 respectively in daylight, night and mix rainfall (Table 2).

In the study, maximum rainfall intensities (IM10, IM15 and IM30) of each erosive rainfall are grouped for different time occurrences (daylight, night and mix rainfall conditions) and we observed the maximum average values in daylight rainfall (Table 2). Average erosive rainfall intensities (IM10, IM15 and IM30) were occurred the second in night and the third in mix rainfall.

Soil losses and runoff values are grouped for three different time occurrences (Table 2). The maximum soil loss and runoff are occurred in night rainfall. Even though in night erosive rainfall had less storm erosivity, event intensity and several time maximum intensities (IM10, IM15 and IM30) than daylight erosive rainfall, the most soil loss and runoff was observed. This result might be caused by day and night differences in soil conditions like infiltration, evaporation, etc. On the other hand, because of the longer mix rainfall duration more rain infiltrated in the soil by decreasing the runoff eventually the soil loss. Various rainfall properties such as the duration, intensity and its energy have more impact on the erosion compared to the rainfall amount. Although, the average erosive night rainfall amount is less than the mix erosive rainfall amount, the maximum runoff occurred in night rainfall because of soil hydraulic conditions.

The study showed that mix erosive rainfall characteristics were common in the Tokat region. However, because these rainfalls have lower event intensity, storm erosivity and several time intensities, they presented lower erosion risk. Interestingly, daylight rainfalls which have higher erosivity parameters (event intensity, storm erosivity and several time intensities) compared to night erosive rainfalls caused less soil loss. It is believed that this situation was caused by the day and night time temperature 
differences causing short time changes in the soil erodibility. As a matter of fact, erosive rainfalls are widely observed during April, May and June, when the day and night time temperatures are quite high.

Table 2. The relation between some properties of the erosive rainfalls and soil losses and runoff in Tokat

\begin{tabular}{|c|c|c|c|c|c|c|c|c|c|c|}
\hline Rainfall time & $\begin{array}{c}\text { Descriptive } \\
\text { statistics }\end{array}$ & $\begin{array}{c}\text { Event } \\
\text { duration } \\
\text { min }\end{array}$ & $\begin{array}{c}\text { Erosive } \\
\text { rainfall } \\
\text { amount } \\
\text { mm }\end{array}$ & $\begin{array}{c}\text { Event } \\
\text { intensity } \\
\mathbf{m m ~ h}^{-1}\end{array}$ & $\begin{array}{l}\text { Storm erosivity } \\
\text { MJ mm ha } \mathbf{~ h}^{-1} \mathbf{h}^{-1}\end{array}$ & $\begin{array}{c}\text { IM10 } \\
\text { mm h}^{-1}\end{array}$ & $\begin{array}{c}\text { IM15 } \\
\text { mm h }^{-1}\end{array}$ & $\begin{array}{c}\text { IM30 } \\
\mathbf{m m ~ h}^{-1}\end{array}$ & $\begin{array}{l}\text { Soil loss } \\
\text { ton ha }\end{array}$ & $\begin{array}{c}\text { Runoff } \\
\mathbf{m m}\end{array}$ \\
\hline \multirow{6}{*}{$\begin{array}{l}\text { Daylight } \\
\text { rainfall }\end{array}$} & Average & 223.11 & 10.15 & 6.92 & 35.72 & 18.31 & 14.25 & 9.68 & 3.87 & 2.43 \\
\hline & Minimum & 18.00 & 0.55 & 0.15 & 1.03 & 1.80 & 1.60 & 1.60 & 0.001 & 0.12 \\
\hline & Maximum & 732.00 & 35.30 & 60.51 & 768.36 & 199.80 & 134.00 & 78.80 & 19.32 & 13.72 \\
\hline & St. dev. & 164.78 & 6.63 & 13.67 & 132.51 & 34.68 & 23.56 & 14.78 & 6.15 & 4.15 \\
\hline & Variance & 27524.78 & 44.19 & 187.44 & 17658.08 & 1205.00 & 555.80 & 218.70 & 38.03 & 17.29 \\
\hline & $\mathrm{CV}$ & 73.86 & 65.38 & 197.55 & 371.01 & 189.43 & 165.35 & 152.74 & 158.99 & 171.03 \\
\hline \multirow{6}{*}{$\begin{array}{l}\text { Night } \\
\text { rainfall }\end{array}$} & Average & 191.58 & 8.71 & 4.51 & 23.80 & 15.20 & 12.34 & 8.57 & 6.78 & 2.91 \\
\hline & Minimum & 18.00 & 2.50 & 0.90 & 0.51 & 2.40 & 1.90 & 1.40 & 0.002 & 0.04 \\
\hline & Maximum & 740.00 & 33.10 & 57.00 & 481.05 & 109.17 & 80.35 & 54.80 & 27.51 & 15.35 \\
\hline & St. dev. & 142.94 & 4.98 & 6.81 & 63.53 & 17.66 & 12.95 & 8.40 & 10.02 & 4.74 \\
\hline & Variance & 20715.69 & 25.11 & 47.04 & 4091.66 & 316.18 & 169.92 & 71.50 & 120.40 & 25.01 \\
\hline & $\mathrm{CV}$ & 74.61 & 57.15 & 150.89 & 266.89 & 116.21 & 104.92 & 97.98 & 147.81 & 163.15 \\
\hline \multirow{6}{*}{$\begin{array}{l}\text { Mix } \\
\text { rainfall }\end{array}$} & Average & 450.18 & 12.44 & 2.60 & 18.65 & 10.73 & 8.72 & 6.32 & 0.79 & 1.66 \\
\hline & Minimum & 25.00 & 0.20 & 0.07 & 0.49 & 0.42 & 0.30 & 1.00 & 0.0003 & 0.01 \\
\hline & Maximum & 2172.00 & 44.30 & 20.67 & 279.35 & 85.23 & 62.97 & 43.00 & 8.22 & 15.92 \\
\hline & St. dev. & 349.41 & 7.89 & 2.86 & 39.10 & 12.92 & 9.40 & 6.20 & 1.68 & 3.07 \\
\hline & Variance & 122630.05 & 62.46 & 8.21 & 1535.35 & 167.54 & 88.80 & 38.67 & 2.90 & 9.59 \\
\hline & $\mathrm{CV}$ & 77.62 & 63.38 & 110.00 & 209.64 & 120.41 & 107.80 & 98.19 & 213.82 & 184.45 \\
\hline
\end{tabular}

Correlations between soil loss, runoff and several time maximum intensities (IM10, IM15 and IM30): Some descriptive statistics for soil loss, runoff and several maximum time intensities are presented in Table 3, which reveals that, the higher $\mathrm{CV}$ of variables occurred in IM10, IM15, IM30, soil loss and runoff respectively. When the maximum intensities are compared, the CV values of IM10 and IM15 are more changeable than IM30.

Table 3. Descriptive statistics of soil loss, runoff and several time maximum intensities

\begin{tabular}{|c|c|c|c|c|c|c|}
\hline Properties & Min. & Max. & Mean & St. dev. & Variance & $\mathrm{CV}$ \\
\hline Soil loss, ton ha ${ }^{-1}$ & 0.0003 & 27.51 & 2.20 & 4.88 & 24.28 & 221.66 \\
\hline Runoff, mm & 0.01 & 15.92 & 2.00 & 3.50 & 12.38 & 174.64 \\
\hline $\mathrm{IM} 10, \mathrm{~mm} \mathrm{~h}^{-1}$ & 0.42 & 199.80 & 13.10 & 18.22 & 332.76 & 139.01 \\
\hline $\mathrm{IM} 15, \mathrm{~mm} \mathrm{~h}^{-1}$ & 0.42 & 134.00 & 10.53 & 12.95 & 168.27 & 123.07 \\
\hline IM $30, \mathrm{~mm} \mathrm{~h}^{-1}$ & 1.00 & 78.80 & 7.43 & 8.45 & 71.57 & 113.77 \\
\hline
\end{tabular}

The correlations between soil loss, runoff, IM10, IM15 and IM 30 are presented in Table 4. According to correlation analyses, there is strong positive correlation between properties (soil loss and runoff) and IM10, IM15 and IM30 values. The IM30 parameter has been shown to be a better predictor of sediment yield than rainfall depth (Foster et 
al., 1982). Even though IM30 is widely adopted in the empirical estimation of event soil loss (Bagarello et al., 2013; Kinnell, 2010), in our study, we found the maximum correlation between soil loss and IM10 values. This may result IM10 values to describe erosivity as a better parameter than IM30 for the region. IM15 values are medium correlated between soil loss and IM15 values, while runoff and IM30 parameters showed maximum correlation.

Table 4. Correlation coefficients between soil loss, runoff, IM10, IM15 and IM 30

\begin{tabular}{|c|c|c|c|}
\hline Properties & IM10, $\mathrm{mm} \mathrm{h}^{-1}$ & IM15, $\mathrm{mm} \mathrm{h}^{-1}$ & IM30, $\mathrm{mm} \mathrm{h}^{-1}$ \\
\hline Soil loss, ton $\mathrm{ha}^{-1}$ & $0.746^{* * *}$ & $0.717^{* *}$ & $0.562^{* *}$ \\
\hline Runoff, mm & $0.805^{* *}$ & $0.781^{* *}$ & $0.815^{* *}$ \\
\hline
\end{tabular}

$* * \mathrm{p}<0.01$

Trend and slope analyses: Trend analysis gave appropriate data to describe trend and slope of some rainfall characteristics, MFI index, soil loss and runoff for the region. The Mann-Kendall test and Sen's slope estimator were used for this purpose. The MannKendall statistics for trend and Sen's slope estimator is given in Table 5 for Tokat city. The Mann-Kendall statistics showed significant trend for all parameters. The Sen's slope estimator had negative slope for research period for all parameters. The calculated $p$ values are smaller than the critical $p$ value from the table of the standard normal distribution. The Ho hypothesis related to no monotonic trend was rejected for all data sets.

Rainfall erosivity is the ability of rainfall to cause erosion due to the function of erosive characteristic of rainfall (Mikhailova et al., 1997). In Tokat region, some physical characteristics of rainfall which is related to rainfall erosivity showed decreasing trend whole study period. Likewise, similar trends exist for soil losses and runoff.

Table 5. Trend and slope results for study area for study period (1978-1995)

\begin{tabular}{c|c|c|c|c}
\hline Parameters & $\mathbf{z}$ & p-value & Sen & CI for Sen \\
\hline Daily rainfall, mm & -3.50 & 0.00 & -0.063 & $(-0.085,-0.044)$ \\
Erosive rainfall, mm & -2.47 & 0.01 & -0.013 & $(-0.019,-0.004)$ \\
Erosive rainfall duration, $\mathrm{h}$ & -3.78 & 0.00 & -0.034 & $(-0.046,-0.025)$ \\
R factor, MJ mm ha ${ }^{-1} \mathrm{~h}^{-1}$ & -2.27 & 0.01 & -0.010 & $(-0.023,-0.002)$ \\
MFI & -3.50 & 0.00 & -0.063 & $(-0.085,-0.044)$ \\
IM10, $\mathrm{mm} \mathrm{h}^{-1}$ & -3.11 & 0.00 & -0.135 & $(-0.187,-0.060)$ \\
IM15, $\mathrm{mm} \mathrm{h}^{-1}$ & -4.05 & 0.00 & -0.070 & $(-0.092,-0.046)$ \\
IM30, $\mathrm{mm} \mathrm{h}^{-1}$ & -2.82 & 0.00 & -0.011 & $(-0.020,-0.005)$ \\
Runoff, $\mathrm{mm}^{\text {Soil loss, ton ha }}{ }^{-1}$ & -3.50 & 0.00 & -0.063 & $(-0.085,-0.044)$ \\
& -2.47 & 0.01 & -0.018 & $(-0.035,-0.004)$ \\
\hline
\end{tabular}

Comparison of $R$ factor with Modified Fournier Index for the region: Computation of the erosion index (EI), which is basic for the determination of the R factor (Rain Factor) of Universal Soil Loss Equation (USLE) is tedious and time consuming and requires continuous records. Although there is pluviometer data in some rural areas but 
pluviograph data is not available in most areas. To handle this handicap some researchers have introduced various indexes or models. The Modified Fournier Index (MFI) is one of them. Several studies (Renard and Freimund, 1994; Diodato and Bellocchi, 2007; Lee and Heo, 2011; Taguas et al., 2013; Yue et al., 2014) have shown a high correlation between the $\mathrm{R}$ factor and rainfall parameters such as the MFI. In this study we used Modified Fournier Index (MFI) and R factor of USLE to estimate and compare each method to describe erosivity. To have a better understanding of MFI performance, 216 monthly MFI values and R factor values were compared. A strong correlation between them $\left(\mathrm{r}=0.516^{* *}\right)$ was obtained. Monthly correlation coefficients and some descriptive between $\mathrm{R}$ and MFI values are given in Table 6. Both methods presented good correlation. The best correlations and maximum coefficient of variance were found in summer session.

Table 6. Monthly correlation coefficients and some descriptive between $R$ and MFI values

\begin{tabular}{c|c|c|c|c|c|c|c|c|c|c|c}
\hline \multirow{2}{*}{ Month } & \multirow{2}{*}{$\begin{array}{c}\text { Correlation } \\
\text { coefficient }\end{array}$} & \multicolumn{7}{|c|}{ R values } & \multicolumn{6}{c}{ MFI values } \\
\cline { 3 - 12 } & Min. & Max. & Mean & St. dev. & CV & Min. & Max. & Mean & St. dev. & CV \\
\hline Jan & $0.822^{* *}$ & 0.00 & 5.22 & 1.86 & 1.61 & 86.56 & 0.35 & 17.16 & 5.72 & 5.31 & 92.83 \\
Feb & $0.707^{* *}$ & 0.00 & 3.61 & 1.16 & 1.04 & 89.66 & 0.59 & 10.54 & 3.24 & 2.61 & 80.56 \\
Mar & $0.694^{* *}$ & 0.00 & 5.03 & 1.22 & 1.43 & 117.21 & 0.01 & 23.86 & 4.03 & 5.49 & 136.23 \\
Apr & $0.632^{* *}$ & 0.79 & 36.05 & 7.45 & 8.65 & 116.11 & 1.52 & 34.27 & 9.34 & 8.93 & 95.61 \\
May & $0.862^{* *}$ & 1.34 & 83.79 & 13.63 & 21.00 & 154.07 & 1.40 & 67.18 & 12.21 & 15.05 & 123.26 \\
Jun & $0.846^{* *}$ & 0.00 & 138.13 & 13.11 & 31.92 & 243.48 & 0.25 & 17.70 & 3.94 & 4.54 & 115.23 \\
Jul & $0.985^{* *}$ & 0.00 & 31.39 & 2.76 & 7.44 & 269.57 & 0.00 & 10.33 & 1.00 & 2.43 & 243.00 \\
Aug & $0.903^{* *}$ & 0.00 & 26.18 & 1.76 & 6.12 & 347.73 & 0.00 & 1.47 & 0.20 & 0.36 & 180.00 \\
Sep & $0.912^{* *}$ & 0.00 & 58.85 & 8.41 & 17.29 & 205.59 & 0.00 & 4.79 & 1.11 & 1.50 & 135.14 \\
Oct & $0.689^{* *}$ & 0.00 & 10.79 & 3.96 & 3.57 & 90.15 & 0.03 & 33.10 & 5.82 & 8.66 & 148.80 \\
Nov & $0.696^{* *}$ & 0.00 & 8.31 & 2.70 & 2.43 & 90.00 & 0.01 & 27.32 & 8.18 & 7.96 & 97.31 \\
Dec & $0.646^{* *}$ & 0.00 & 3.00 & 1.09 & 0.83 & 76.15 & 0.63 & 15.66 & 4.46 & 3.57 & 80.04 \\
\hline
\end{tabular}

$* * p<0.01$

\section{Conclusion}

The rain gauge data from 1978 to 1995 were analyzed for Tokat, located in the middle Black Sea region in Turkey, in order to characterize rainfall erosivity. The annual average rainfall was $452 \mathrm{~mm}$. The EI values of the erosive rainfalls during the research period generally were low. A significant portion of the erosive rainfalls is lower than $10 \mathrm{~mm}$. Erosive rainfalls usually took place during April, May and June. The highest EI values observed during the daylight erosive rainfalls, however with the temperature increasing during the day soil presented lower erodibility. It is assumed that this situation is linked to the higher soil temperature observed during the daylight rainfalls increasing the infiltration and evaporation, causing lower levels of runoff. Taking this result into consideration, it is recommended to carry out rainfall erosivity studies considering the soil losses and runoff as well. Rainfall erosivity studies carried out supported by soil losses and runoff will provide more reliable results.

Night erosive rainfalls which presents highest soil loss and runoff, created only $19.57 \%$ of all the erosive rainfalls. Although they have lower EI value than the daylight rainfalls, night erosive rainfalls caused more soil loss and runoff. Night erosive rainfalls almost created twice the soil loss compared to daylight rainfalls. 
The Modified Fournier Index (MFI) was calculated using long term monthly data between 1978 and 1995. The MFI and R factor of USLE was compared and presented a strong correlation between them. This result shows MFI is useful an index to estimate rainfall erosivity which is not available pluviograph data for Tokat region.

According to trend analysis test results, the revealed findings indicated that the negative trends of all test parameters for the region. Considering to this result, a decrease tendency was determined in the erosion parameters of the region over time.

Tokat region rainfalls presented low erosivity. Mostly mix erosive rainfalls were occurred in study period. Mix erosive rainfalls have longer event duration but lower energy. Therefore, these rainfalls have lower erosion risk. Erosive rainfalls form almost $61 \%$ of the erosive rains. Although daylight and night erosive rainfalls have higher erosion risk, being low in ratio decreases the erosion risk. Soil losses can be taken under control by applying cultural practices on individual farmer basis, such as contour farming, no tillage, forage crop farming etc. Taking these precautions for sustainable farming does not create high levels of costs.

\section{REFERENCES}

[1] Araya, T., Cornelis, W. M., Nyssen, J., Govaerts, B., Bauer, H., Gebreegziabher, T., Oicha, T., Raes, D., Sayre, K. D., Haile, M., Decker, J. (2011): Effects of conservation agriculture on runoff, soil loss and crop yield under rainfed conditions in Tigray, Northern Ethiopia. - Soil Use and Management 27: 404-414.

[2] Arnoldus, H. (1977): Methodology used to determine the maximum potential average annual soil loss due to sheet and rill erosion in Morocco. - FAO Soils Bulletin 34: 39-51.

[3] Baartman, J. E., Temme, A. J., Veldkamp, T., Jetten, V. G., Schoorl, J. M. (2013): Exploring the role of rainfall variability and extreme events in long-term landscape development. - Catena 109: 25-38.

[4] Bagarello, V., Ferro, V., Giordano, G., Mannocchi,. F., Todisco, F., Vergni, L. (2013): Predicting event soil loss from bare plots at two Italian sites. - Catena 109: 96-102.

[5] Beasley, D. B., Huggins, L. F., Monke, E. J. (1989): ANSWERS: a model for watershed planning. - Transactions of the American Society of Agricultural Engineers 23(4): 938944.

[6] Busnelli, J., Neder. L. V., Sayago. J. M. (2006): Temporal dynamics of soil erosion and rainfall erosivity as geoindicators of land degradation in northwestern Argentina. Quaternary International 158(1): 147-161.

[7] Cerdan, O., Govers, G., Bissonnais, Y., Oost, K., Poesen, J., Saby, N., Gobin, A., Vacca, A., Quinton, J., Auerswald, K., Klik, A., Kwaad, F. J. P. M., Raclot, D., Ionita, I., Rejman, J., Rousseva, S., Muxart, T., Roxo, M. J., Dostal, T. (2010): Rates and spatial variations of soil erosion in Europe: a study based on erosion plot data. - Geomorphology 122(1-2): 167-177.

[8] Diodato, N., Bellocchi, G. (2007): Estimating monthly (R)USLE climate input in a Mediterranean region using limited data. - Journal of Hydrology 345: 224-236.

[9] Efthimiou, N. (2018): Evaluating the performance of different empirical rainfall erosivity (R) factor formulas using sediment yield measurements. - Catena 169: 195-208.

[10] Eltaif, N., Gharaibeh, M., Al-Zaitawi, F., Almahad, M. (2010): Approximation of rainfall erosivity factors in North Jordan. - Pedosphere 20: 711-717.

[11] FAO (1977): Assessing Soil Degredation. - Soils Bulletin 34. FAO, Rome.

[12] Ferro, V., Giordano, G., Lovino, M. (1991): Isoerosivity and erosion riskmap for Sicily. Hydrological Sciences Journal 36(6): 549-564. 
[13] Foster, G. R., Osterkamp, W. R., Lane, L. J., Hunt, D. W. (1982): Effect of Discharge Rate on Rill Erosion. - ASAE Winter Meeting, Chicago, American Society of Agricultural Engineers, Paper 82-2572.

[14] Foster, G. R., Yoder, D. C., Weesies, G. A., McCool, D. K., McGregor, K. C., Bingner, R. L. (2003): Draft User's Guide, Revised Universal Soil Loss Equation Version 2 (RUSLE-2), - USDA-Agricultural Research Service, Washington, DC.

[15] Fournier, F. (1960): Climat et erosion: la relation entre l'erosion du sol par l'cau et les precipitations atmospheriques. - Presses Universitaies de France, Paris.

[16] Hudson, N. (1971): Soil Conservation. Second Edition. - B. T. Batsford, London.

[17] Jefferson, S., Ildegardis, B., Neroli, P. C., Antonio, P. G. (2014): Erosivity of rainfall in Lages. Santa Catarina. - Revista Brasileira de Ciência do Solo 38(6): 1890-1905.

[18] Jingi, B. B., Danladi, D. D., Abdukadir, S. A., Abubakar, Y. (2011): The effect of rainfall on aggregate stability and splash erosion on some agricultural soils of Borno State, Nigeria. - AU Journal of Technology 15(1): 45-48.

[19] Katebikord, A., Darvishan, A. K., Alavi, S. J. (2017): Changeability of soil erosion variables in small field plots from different rainfall durations with constant intensity. Journal of African Earth Sciences 129: 751-758.

[20] Kendall, M. G. (1975): Rank Correlation Methods. Fourth Edition. - Charles Griffin, London.

[21] Kinnell, P. I. A. (2010): Event soil loss, runoff and the Universal Soil Loss equation family of models: a review. - Journal of Hydrology 385(1-4): 384-397.

[22] Lal, R. (1976): Soil erosion on Alfisols in Western Nigeria. III. Effects of rainfall characteristics. - Geoderma 16: 389-401.

[23] Lee, J. H., Heo. J. H. (2011): Evaluation of estimation methods for rainfall erosivity based on annual precipitation in Korea. - Journal of Hydrology 409: 30-48.

[24] Mann, H. B. (1945): Non-parametric test against trend. - Econometrica 13: 245-259.

[25] Martínez, A. M., Beguería, S. (2009): Estimating rainfall erosivity from daily precipitation records: a comparison among methods using data from the Ebro Basin (NE Spain). - Journal of Hydrology 379: 111-121.

[26] Mikhailova, E. A., Bryant, R. B., Schwager. S. J., Smith, S. D. (1997). Predicting rainfall erosivity in Honduras. - Journal of Soil Science Society of America 61(1): 273-279.

[27] Mohamadi, M. A., Kavian, A. (2015): Effects of rainfall patterns on runoff and soil erosion in field plots. - International Soil and Water Conservation Research 3: 273-281.

[28] Mohtar, Z. A., Yahaya, A. S., Ahmad, F. (2015): Rainfall erosivity estimation for Northern and Southern peninsular Malaysia using Fourneir indexes. - Procedia Engineering 125: 179-184.

[29] Oguz, I., Cebel, H., Ozden, S., Ayday, E., Demiryurek, M. (2006): Turkiye universal denklem toprak kaybı esitligi rehberi. - TAGEM-BB-TOPRAKSU 2006-01, Enstitu Yayin No: 225-41 (in Turkish).

[30] Phan, H. A., Huon, S., Henry, Tureaux, T. H., Orange, D., Jouquet, P., Valentin, C., Rouw, A., Tran, T. T. (2012): Impact of fodder cover on runoff and soil erosion at plot scale in a cultivated catchment of North Vietnam. - Geoderma 177: 8-17.

[31] Renard, K. G., Freimund, J. R. (1994): Using monthly precipitation data to estimate the R-factor in the revised USLE. - Journal of Hydrology 157: 287-306.

[32] Richardson, C. W., Foster, G. R., Wright, D. A. (1983): Estimation of erosion index from daily rainfall amount. - Transactions of the American Society of Agricultural Engineers 26: $153-157$.

[33] Salako, F. K. (2008): Rainfall variability and kinetic energy in southern Nigeria. Climatic Change 86: 151-164.

[34] Salako, F. K., Ghuman, B. S., Lal, R. (1995): Rainfall erosivity in south-central Nigeria. - Soil Technology 7: 279-290.

[35] Sanchez-Moreno, J. F., Mannaerts, C. M. M., Jetten, V. (2014): Rainfall erosivity mapping for Santiago Island, Cape Verde. - Geoderma 217-218: 74-82. 
[36] Sharpley, A. N., Williams, J. R. (1990): EPIC: Erosion/Productivity Impact Calculator: 1. Model Documentation. - USDA Technic Bulletin, No: 1768, Agricultural Research Service, United States Department of Agriculture, Washington. D. C.

[37] Sauerborn, P., Klein, A., Botschek, J., Skowronek, A. (1999): Future rainfall erosivity derived from large-scale climate models - methods and scenarios for a humid region. Geoderma 93: 269-276.

[38] Sukhanovski, Y. P., Ollesch, G., Khan, K. Y., Meißner, R. (2002): A new index for rainfall erosivity on a physical basis. - Journal of Plant Nutrition and Soil Science 165: 51-57.

[39] Taguas, E. V., Carpintero, E., Ayuso, J. L. (2013): Assessing land degradation risk through the long-term analysis of erosivity: a case study in southern Spain. - Land Degradation and Development 24: 179-187.

[40] Todisco, F. (2014): The internal structure of erosive and non-erosive storm events for interpretation of erosive processes and rainfall simulation. - Journal of Hydrology 519: 3651-3663.

[41] Wang, L., Shi, Z. H., Wang, J., Fang, N. F., Wu, G. L., Zhang, H. Y. (2014): Rainfall kinetic energy controlling erosion processes and sediment sorting on steep hillslopes: a case study of clay loam soil from the Loess Plateau, China. - Journal of Hydrology 512: 168-176.

[42] Wischmeier, W. H., Smith, D. D. (1958): Rainfall energy and its relation to soil loss. Transactions of the American Geophysical Union 39: 285-291.

[43] Wischmeier, W. H., Smith, D. D. (1978): Predicting Rainfall Erosion Losses: A Guide to Conservation Planning. - United States Department of Agriculture (USDA), Agricultural Handbook No. 537, United States Government Printing Office, Washington. D. C.

[44] Xie, Y., Yin, S., Liu, B., Nearing, M. A., Zhao, Y. (2014): Models for estimating daily rainfall erosivity in China. - Journal of Hydrology 535: 547-558.

[45] Young, R. A., Onstad, C. A., Bosch, D. D., Anderson, J. P. (1989): AGNPS: A non pointsource pollution model for evaluating agricultural watersheds. - Journal of Soil and Water Conservation 44(2): 4522-4561.

[46] Yu, B., Rosewell, C. J. (1996a): An assessment of a daily rainfall erosivity model for New South Wales. - Australian Journal of Soil Research 34: 139-152.

[47] Yu, B., Rosewell, C. J. (1996b): A robust estimate of the R-Factor for the Universal Soil Loss Equation. - Transactions-American Society of Agricultural Engineers 39(2): 559561.

[48] Yue, B. J., Shi, Z. H., Fang, N. F. (2014): Evaluation of rainfall erosivity and its temporal variation in the Yanhe River catchment of the Chinese Loess Plateau. - Natural Hazards 74: 585-602.

[49] Yurekli, K. (2015): Impact of climate variability on precipitation in the Upper EuphratesTigris Rivers Basin of Southeast Turkey. - Atmospheric Research 154: 25-38. 